Unnes Journal of Public Health

\title{
HUBUNGAN TINGKAT KELEMBABAN RUMAH TINGGAL DENGAN KEJADIAN TUBERKULOSIS PARU DI WILAYAH KECAMATAN TULIS KABUPATEN BATANG
}

\author{
Novita Indriyani $^{1}$, Nor Istiqomah ${ }^{1}$, M.Choiroel Anwar ${ }^{2}$ \\ ${ }^{1}$ Prodi Kesehatan Masyarakat, Fakultas Ilmu Kesehatan, Universitas Pekalongan, Indonesia \\ ${ }^{2}$ Akademi Kesehatan Lingkungan Purwokerto, Indonesia
}

\section{Info Artikel}

Sejarah Artikel:

Diterima 1 Juli 2016

Disetujui 2 Juli 2016

Dipublikasikan Juli 2016

Keywords:

Pulnomary

tuberculosis; indoor

humidity; Tulis regency

\begin{abstract}
Abstrak
Salah satu penyakit menular yang menjadi perhatian dan masalah kesehatan masyarakat di wilayah Kecamatan Tulis adalah TB paru yang meningkat setiap tahunnya, dengan angka prevalensi tahun 2014 sebesar 83,4/100.000 penduduk. Salah satu faktor yang mempengaruhi adanya agen bakteri tuberkulosis yaitu lingkungan rumah tinggal. Tujuan penelitian mengetahui hubungan tingkat kelembaban rumah tinggal dengan kejadian TB paru di wilayah kecamatan Tulis. Desain penelitian case control, variabel bebas yang diteliti yaitu tingkat kelembaban, dan variabel confounding adalah luas ventilasi, keberadaan jendela, pencahayaan, dan suhu. Sampel penelitian 70 responden, terdiri dari 35 kasus dan 35 kontrol. Hasil analisis bivariat uji chi square bahwa ada hubungan antara tingkat kelembaban $(p=0,004$ OR=4,792) dan pencahayaan ( $p=0,031 O R=3,273)$ dengan TB paru. Analisis multivariat yang terbukti sebagai faktor resiko adalah tingkat kelembaban $(O R=3,801)$ dikontrol pencahayaan $(O R=1,456)$.
\end{abstract}

\section{Abstract}

Pulmonary tuberculosis disease is one of infectious disease that becomes major health problem in districts Tulis wich was increasing every year with prevalence rate 83.4 / 100,000 in 2014. One factor that affect the existance of bacterial agent of tuberculosis is environment, including indoor humudity. This research aimed to determine relationship between indoor humidity with pulmonary tuberculosis. This was a case control study. The confounding variables in this study were total vent area, window number, illuminance and temperature. Bivariate analysis showed that pulmonary tuberculosis insidence correlated to both humidity $(p=0,004$ $O R=4,792)$ and illuminance $(p=0,031 O R=3.273)$. Multivariat analysis showed that incidence of pulmonary tuberculosis was correlated with humidity $(O R=3.801)$ and controlled by illuminance $(O R=$ 1.456).

(C) 2015 Universitas Negeri Semarang

\footnotetext{
Alamat korespondensi:

Prodi Kesehatan Masyarakat , Fakultas Ilmu Kesehatan

Universitas Pekalongan, Gedung D Lantai 1 JL. Sriwijaya No.3

Pekalongan

E-mail: novitaindriyani110@yahoo.co.id
}

ISSN 2252-6781 


\section{PENDAHULUAN}

TB paru merupakan penyakit kedua setelah HIV AIDS sebagai pembunuh terbesar diseluruh dunia. Pada tahun 2009, terdapat sekitar 9,4 juta insiden kasus TB paru secara global prevalensinya di dunia mencapai 14 juta kasus atau sama dengan 200 kasus per 100.000 penduduk (Depkes RI, 2011).

Di Kabupaten Batang berdasarkan Indikator Evaluasi Program Pemberantasan dan Pengendalian TB paru tahun 2014 sebesar 665 kasus. Angka prevalensinya 92 per 100.000 penduduk (Dinkes Batang, 2014). Peningkatan kasus terjadi di beberapa Puskesmas, salah satunya Puskesmas Tulis. Dari tahun 2012 ada 25 kasus, tahun 2013 tercatat 28 kasus dan meningkat tahun 2014 menjadi 36 kasus. Angka cakupan penemuan kasus TB paru BTA positif (CDR) tahun 2013 sebesar $37,1 \%$ dan tahun 2014 sebesar $71,6 \%$. Hal ini menunjukkan bahwa di Kecamatan Tulis kasus TB paru masih tinggi. Data penderita TB paru tidak masuk dalam register penderita HIV/AIDS (Profil Puskesmas Tulis, 2014).

Sementara kondisi rumah tinggal di Kecamatan Tulis tahun 2014 dari 9.572 rumah, terdapat 5.902 rumah permanen dan 3.673 rumah tidak permanen. Kondisi rumah yang memenuhi syarat kesehatan baru mencapai 23,4\%, berarti masih dibawah $80 \%$ penduduk dalam rumah sehat (BPS Batang, 2014). Survei pendahuluan yang telah dilakukan pada 15 rumah mendapatkan hasil antara lain 2 rumah sehat, 8 rumah jarang membuka jendela kamar dan 5 rumah tidak memiliki jendela.

TB paru adalah penyakit menular yang disebabkan oleh Mycobaclerium tuberculosis yang dapat ditularkan melalui udara (droplet nuclei) saat seorang pasien

tuberkulosis batuk dan percikan ludah yang mengandung bakteri terhirup oleh orang lain saat bernapas. Sumber penularan adalah pasien TB paru BTA positif (Tiwari et al, 2012; Wankhade et al, 2012; Widoyono, 2008).

Lingkungan yang tidak sehat (kumuh) merupakan tempat yang baik dalam menularkan penyakit seperti tuberkulosis. Lingkungan rumah yang berhubungan dengan kejadian tuberkulosis yaitu tingginya kelembaban yang dipengaruhi oleh kurangnya ventilasi, keberadaan jendela yang tidak berfungsi, kurangnya pencahayaan dan suhu yang rendah (Lienhardt et al, 2001; Kizito et al, 2010).

Berdasarkan teori konsep penyebab penyakit, TB paru termasuk salah satu penyakit dengan konsep web of causation yaitu dengan banyak penyebab. Jenis penyebab utama (necessary factor) yaitu agen yang harus ada agar terjadi suatu penyakit yaitu Mycobacterium tuberculosis. Jenis penyebab kedua atau sufficient factor yaitu faktor pendukung agent yang menyebabkan terjadinya penyakit seperti kelembaban lingkungan rumah. Sedangkan kelembaban dipengaruhi oleh ventilasi, jendela, pencahayaan dan suhu yang merupakan Faktor yang berkontribusi pada tingkat kelembaban (Contributory factor) (Bartram et al, 2010; Sarwani et al, 2012; Fitriani, 2013).

Tujuan penelitian ini untuk mengetahui hubungan tingkat kelembaban rumah tinggal dengan kejadian TB paru dengan dikontrol variabel luas ventilasi, keberadaan jendela, pencahayaan dan suhu.

\section{METODE}


Jenis penelitian analitik observasional dengan menggunakan metode case control yaitu membandingkan antara kelompok kasus dengan kelompok kontrol berdasarkan status penyakitnya.

Populasi Kasus adalah penderita yang dinyatakan TB paru tercatat di UPK Puskesmas Tulis dari bulan Agustus 2014 sampai Mei 2015. Populasi kontrol dari data registrasi pengunjung rawat jalan di Puskesmas Tulis yang tidak menderita TB paru, ISPA, Asma maupun penyakit yang dicurigai tuberkulosis lainnya. Sampel penelitian menggunakan seluruh kasus TB paru dengan jumlah 35 orang dan kontrol 35 orang. Semua responden tinggal pada rumah yang tidak mengalami perubahan fisik sejak tahun 2010.

Data yang digunakan data primer (register TB paru UPK Puskesmas Tulis) dan sekunder dengan cara pengukuran dan observasional menggunakan cheklist. Pengukuran tingkat kelembaban (hygrometer), luas ventilasi (rollmeter), pencahayaan (luxmeter), suhu (thermometer).
Observasi pengamatan pada jendela rumah yang jarang dibuka (jendela rusak/tidak dapat difungsikan).

Analisis data antara lain Univariat mendeskripsikan TB paru, tingkat kelembaban rumah tinggal dan variabel yang mempengaruhi keduanya (luas ventilasi, keberadaan jendela, tingkat pencahayaan dan suhu). Bivariat melihat hubungan kelembaban dengan TB paru, menggunakan uji chi-square dengan menggunakan power sebesar $80 \%$, dan tingkat kemaknaan $(\alpha=0,05)$. Multivariat untuk mengetahui peran variabel confounding yang mempengaruhi variabel bebas dan variabel terikat, menggunakan uji regresi logistik.

\section{HASIL DAN PEMBAHASAN}

Analisis univariat mendeskripsikan hasil pengukuran dan observasi tingkat kelembaban, ventilasi, jendela, tingkat

pencahayaan dan suhu.

Tabel 1. Hasil analisis Univariat

\begin{tabular}{|c|c|c|c|c|c|c|c|c|}
\hline \multirow{3}{*}{ Variabel } & \multicolumn{4}{|c|}{ Responden } & \multirow{2}{*}{\multicolumn{2}{|c|}{ Total }} & \multicolumn{2}{|l|}{ Nilai } \\
\hline & \multicolumn{2}{|c|}{ Kasus } & \multicolumn{2}{|c|}{ Kontrol } & & & \multirow{2}{*}{$\begin{array}{l}\text { Mea } \\
n\end{array}$} & \multirow{2}{*}{$\begin{array}{l}\text { Std } \\
\text { Deviasi }\end{array}$} \\
\hline & $\mathrm{N}$ & $\%$ & $\mathrm{~N}$ & $\%$ & $\bar{N}$ & $\%$ & & \\
\hline \multicolumn{9}{|l|}{ Tingkat Kelembaban } \\
\hline$>70 \%$ & 23 & 65,7 & 10 & 28,6 & 33 & 47,1 & 69,2 & 4,936 \\
\hline Antara $40-70 \%$ & 12 & 34,3 & 25 & 71,4 & 37 & 52,9 & 4 & \\
\hline \multicolumn{9}{|l|}{ Luas Ventilasi } \\
\hline$<10 \%$ Luas Lantai & 18 & 51,4 & 16 & 45,7 & 34 & 48,6 & 8,83 & 3,738 \\
\hline$\geq 10 \%$ Luas Lantai & 17 & 48,6 & 19 & 54,3 & 36 & 51,4 & & \\
\hline \multicolumn{9}{|l|}{ Keberadaan Jendela } \\
\hline Tidak (tertutup) & 22 & 62,8 & 16 & 45,7 & 38 & 54,3 & - & - \\
\hline Ya (Terbuka) & 13 & 37,2 & 19 & 54,3 & 32 & 45,7 & & \\
\hline \multicolumn{9}{|l|}{ Tingkat Pencahayaan } \\
\hline$<60 \mathrm{Lux}$ & 24 & 68,6 & 14 & 40,0 & 38 & 54,3 & 57,8 & 13,385 \\
\hline$\geq 60 \mathrm{Lux}$ & 11 & 31,4 & 21 & 60,0 & 32 & 45,7 & 3 & \\
\hline \multicolumn{9}{|l|}{ Suhu } \\
\hline$<20^{\circ} \mathrm{C}$ & 0 & 0 & 0 & 0 & 0 & 0 & 28,4 & 0,999 \\
\hline
\end{tabular}




\begin{tabular}{llllllll}
\hline $20^{\circ} \mathrm{C}-30^{\circ} \mathrm{C}$ & 35 & 100 & 35 & 100 & 70 & 100 & 0 \\
\hline
\end{tabular}

Dari tabel 1 hasil pengukuran suhu pada seluruh responden berkisar antara $20^{\circ} \mathrm{C}$ sampai $30^{\circ} \mathrm{C}$ dengan kategori memenuhi syarat. Tingkat kelembaban lebih dari $70 \%$ paling banyak pada kelompok kasus. Pada luas ventilasi 48,6\% rumah responden memiliki luas $<10 \%$ dari luas lantai dengan rata-rata 8,83\%. Dari 70 responden $54,3 \%$ rumah dengan kondisi jendela tertutup/tidak ada jendela dan tingkat pencahayaan $<60$ Lux. Rata-rata tingkat pencahayaan rumah tinggal responden yaitu 57,8 Lux tidak memenuhi syarat.

Analisis bivariat untuk mengetahui hubungan antar variabel bebas dengan variabel terikat dan variabel counfounding, menggumakan uji chi square.

Tabel 2. Hubungan antara tingkat kelembaban dengan kejadian TB paru

\begin{tabular}{lllllll}
\hline Tingkat Kelembaban & \multicolumn{2}{l}{ Kasus } & \multicolumn{2}{c}{ Kontrol } & \multicolumn{2}{c}{ Jumlah } \\
\cline { 2 - 7 } & $\mathrm{N}$ & $\%$ & $\mathrm{~N}$ & $\%$ & $\mathrm{~N}$ & $\%$ \\
\hline$>70 \%$ & 23 & $65,7 \%$ & 10 & $28,6 \%$ & 33 & $47,1 \%$ \\
Antara $40-70 \%$ & 12 & $34,3 \%$ & 25 & $71,4 \%$ & 37 & $52,9 \%$ \\
\hline \multicolumn{1}{c}{ OR $=4,792$} & CI $95 \%=1,741<\mathrm{OR}<13,188$ & & nilai $\rho=0,004$ \\
\hline
\end{tabular}

Tabel 3. Analisis hubungan ventilasi (counfounding) dengan TB paru

\begin{tabular}{lllllll}
\hline Luas Ventilasi & \multicolumn{2}{c}{ Kasus } & \multicolumn{3}{c}{ Kontrol } & \multicolumn{3}{c}{ Jumlah } \\
\cline { 2 - 7 } & $\mathrm{N}$ & $\%$ & $\mathrm{~N}$ & $\%$ & $\mathrm{~N}$ & $\%$ \\
\hline$<10 \%$ dari luas lantai & 18 & 51,4 & 16 & 45,7 & 34 & 48,6 \\
$\geq 10 \%$ dari luas lantai & 17 & 38,6 & 19 & 54,3 & 36 & 51,4 \\
\hline OR $=1,257$ & CI $95 \%=0,492<\mathrm{OR}<3,215$ & \multicolumn{3}{c}{ nilai $\rho=0,811$} \\
\hline
\end{tabular}

Tabel 4. Analisis hubungan jendela (counfounding) dengan TB paru

\begin{tabular}{lllllll}
\hline Keberadaan Jendela & \multicolumn{2}{c}{ Kasus } & \multicolumn{2}{c}{ Kontrol } & \multicolumn{2}{c}{ Jumlah } \\
\cline { 2 - 7 } & $\mathrm{N}$ & $\%$ & $\mathrm{~N}$ & $\%$ & $\mathrm{~N}$ & $\%$ \\
\hline Tidak (Tertutup) & 22 & 62,8 & 16 & 45,7 & 38 & 54,3 \\
Ya (Terbuka) & 13 & 37,2 & 19 & 54,3 & 32 & 45,7 \\
\hline OR $=2,010$ & CI $95 \%=0,773<$ OR $<5,223$ & \multicolumn{3}{c}{ nilai $\rho=0,230$} \\
\hline
\end{tabular}

Tabel 5. Analisis hubungan pencahayaan (confounding) dengan TB paru

\begin{tabular}{|c|c|c|c|c|c|c|}
\hline \multirow[t]{2}{*}{ Tingkat Pencahayaan } & \multicolumn{2}{|c|}{ Kasus } & \multicolumn{2}{|c|}{ Kontrol } & \multicolumn{2}{|c|}{ Jumlah } \\
\hline & $\overline{\mathrm{N}}$ & $\%$ & $\mathrm{~N}$ & $\%$ & $\mathrm{~N}$ & $\%$ \\
\hline$<60 \operatorname{Lux}$ & 24 & $68,6 \%$ & 14 & $40,0 \%$ & 38 & $54,3 \%$ \\
\hline$\geq 60 \mathrm{Lux}$ & 11 & $31,4 \%$ & 21 & $60,0 \%$ & 32 & $45,7 \%$ \\
\hline $\mathrm{OR}=3,273$ & CI $95 \%=1,22$ & $\overline{\mathrm{OR}}<8,748$ & & & $=0$ & \\
\hline
\end{tabular}

Kelembaban rumah yaitu banyaknya uap air yang terkandung dalam ruangan. Kelembaban lebih dari $70 \%$ merupakan sarana yang baik untuk pertumbuhan mikroorganisme terutama Mycobacterium tuberculosis, karena di tempat tersebut bakteri ini berkembang biak dengan baik (Depkes RI, 2007). 
Dari hasil uji chi square diperoleh $\mathrm{p}$ value tingkat kelembaban 0,004 artinya ada hubungan bermakna kelembaban rumah dengan kejadian TB paru. Hasil OR = 4,792 rumah dengan kelembaban tinggi akan mempengaruhi penghuninya untuk terkena TB paru sebanyak 4,792 kali

dibanding dengan rumah tingkat kelembaban rendah. Hasil penelitian ini sejalan dengan penelitian Fatimah tahun 2008 yang membuktikan bahwa seseorang yang tinggal dengan kelembaban tinggi beresiko terkena penyakit TB paru 2,571 dibandingkan dengan seseorang yang rumah tinggalnya dengan kelembaban rendah.

Pencahayaan sinar matahari dapat dimanfaatkan untuk pencegahan penyakit TB paru dengan cara mengusahakan masuknya sinar matahari ke dalam rumah. Bakteri TB paru dapat hidup bertahuntahun lamanya dan akan mati bila terkena sinar matahari (Depkes RI, 2008; MalecheObimbo et al, 2015). Cahaya matahari untuk membunuh bakteri tersebut minimal 60 Lux dengan syarat tidak menyilaukan.

Dari hasil uji chi square diperoleh $\mathrm{p}$ value sebesar 0,031 sehingga ada hubungan pencahayaan dengan kejadian TB paru, diketahui $\mathrm{OR}=3,273$ dengan demikian dapat dinyatakan bahwa seseorang yang memiliki pencahayaan rumah $<60$ Lux beresiko terkena penyakit TB paru 3,273 kali lebih besar dibandingkan seseorang yang tinggal dengan tingkat pencahayaan $\geq$ 60 Lux. Penelitian ini sejalan dengan

penelitian Ruswanto tahun 2010, berdasarkan OR yang diperoleh 3,333 ada hubungan antara pencahayaan alami dengan kejadian TB paru di Kabupaten Pekalongan. Akan tetapi berbeda dengan hasil penelitian Iqbal Daroja tahun 2010, dengan nilai $p=0,13$ yang artinya tingkat pencahayaan bukan merupakan faktor resiko kejadian TB paru di Kecamatan Peterongan Jombang. Tingkat pencahayaan dalam suatu ruangan dipengaruhi oleh keberadaan jendela/ ada tidaknya jendela karena dapat membantu sinar matahari yang masuk ke dalam rumah.

Ventilasi mempengaruhi proses dilusi udara, dengan kata lain dapat mengencerkan konsentrasi bakteri tuberkulosis serta bakteri lain terbawa keluar dan mati karena sinar matahari (Ahmadi, 2010; Wulandari, 2012).

Dari hasil uji chi square diperoleh $\mathrm{p}$ value sebesar 0,811 berarti luas ventilasi tidak ada hubungan dengan kejadian TB paru, $\mathrm{OR}=1,257$ kemungkinan penghuni dengan ventilasi $<10 \%$ dari luas lantai beresiko 1 kali lebih besar dari rumah yang memiliki ventilasi $\geq 10 \%$. Hal ini sesuai dengan penelitian Mareta tahun 2014 didapatkan nilai $p$ sebesar 0,569 yang berarti tidak ada hubungan luas ventilasi

dengan TB paru di Puskesmas Kedungmundu Semarang. Rumah yang tidak memiliki ventilasi akan mengakibatkan terhalangnya proses pertukaran aliran udara dan sinar matahari yang masuk ke dalam rumah.

Keberadaan jendela terbuka pada siang hari merupakan salah satu syarat untuk menentukan kualitas udara di dalam ruangan dari pencemaran mikroorganisme salah satunya adalah Mycobacterium tuberculosis (Wulandari, 2012; Suharyo, 2013)

Dari hasil uji chi square, diperoleh $\mathrm{p}$ value sebesar 0,230 artinya tidak ada hubungan yang bermakna keberadaan jendela dengan $\mathrm{TB}$ paru. $\mathrm{OR}=2,010$ kemungkinan rumah dengan jendela tertutup beresiko bagi penghuninya terkena TB paru 2 kali lebih besar dari rumah yang jendelanya terbuka pada siang hari. Penelitian ini sama dengan penelitian 
Ruswanto tahun 2010 diperoleh $\mathrm{p}$ value 0,162 dan $\mathrm{OR}=1,636$ artinya tidak ada hubungan keberadaan jendela dengan TB paru di Kabupaten Pekalongan.
Analisis Multivariat untuk mengetahui peran variabel pengganggu atau confounding menggunakan uji regresi logistik.

Tabel 6. Hasil analisis variabel confounding dari hubungan tingkat kelembaban Rumah Tinggal dengan TB paru

\begin{tabular}{llll}
\hline Variabel & $\mathrm{p}$ & Exp (B) & CI 95\% \\
\hline Tingkat Kelembaban & 0,039 & 3,801 & $1,069<\mathrm{OR}<13,517$ \\
Tingkat Pencahayaan & 0,562 & 1,456 & $0,409<\mathrm{OR}<5,182$ \\
\hline
\end{tabular}

Hasil uji regresi logistik model faktor resiko, variabel tingkat kelembaban nilai $\mathrm{p}$ $=0,039$ yang artinya tingkat kelembaban rumah tinggal sangat berpengaruh dengan kejadian tuberkulosis paru, dan OR $=3,801$ dengan demikian rumah tinggal dengan kelembaban tinggi beresiko 3,8 kali bagi penghuninya terkena $\mathrm{TB}$ paru. Uji confounding pencahayaan didapatkan nilai $\mathrm{p}$ $=0,562$ dan $\mathrm{OR}=1,456$ ditetapkan bahwa tingkat pencahayaan sebagai variabel confounding dari tingkat kelembaban dan tuberkulosis paru.

\section{SIMPULAN}

Ada hubungan antara kelembaban, pencahayaan dengan TB paru di wilayah Kecamatan Tulis. Tidak ada hubungan antara suhu, ventilasi dan jendela dengan TB paru di wilayah Kecamatan Tulis. Ada hubungan tingkat kelembaban dengan TB paru setelah dikontrol dengan tingkat pencahayaan.

\section{UCAPAN TERIMA KASIH}

Ucapan terima kasih disampaikan kepada Dinas Kesehatan Kabupaten Batang dan Puskesmas Tulis dengan segenap jajarannya atas dukungan moril maupun materiil sehingga penelitian ini dapat dilaksanakan dengan baik.

\section{DAFTAR PUSTAKA}

Achmadi, 2012. Manajemen Penyakit Berbasis Wilayah, Rajawali Pers, Jakarta, Edisi revisi cetakan pertama

Bartram, Jamie. and Cairncross, Sandy. 2010. Hygiene, Sanitation, and Water: Forgotten Foundations of Health. PLoS Med 7(11): e1000367. doi:10.1371/journal.pmed.1000367

BPS Kabupaten Batang, 2015. Data monografi Kecamatan Tulis dalam angka 2014, Kabupaten Batang. http://Batangkab.bps.go.id Diakses 2 Juli 2015

Chakaya, Jeremiah., Kirenga, Bruce. \& Getahun, Haileyesus. 2016. Long term complications after completion of pulmonary tuberculosis treatment: $A$ quest for a public health approach. Journal of Clinical Tuberculosis and Other Mycobacterial Diseases. 3 (2016): 10-12

Daroja, I, 2012. Pengaruh Jenis lantai, dinding, ventilasi, pencahayaan, kelembaban, serta pengetahuan terhadap kejadian tuberkulosis paru di Kecamatan Peterongan Kabupaten Jombang. Diakses 13 Maret 2015

Depkes RI, 2007. Pedoman Nasional Penanggulangan Tuberkulosis, Jakarta: Depkes, Edisi dua catatan pertama. 
Depkes RI, 2011. Pedoman Nasional Penanggulangan R, Tuberkulosis, Jakarta: Depkes, Edisi Kedua

Fatimah S, 2008. Faktor kesehatan lingkungan rumah yang berhubungan dengan kejadian TB paru di Kabupaten Cilacap, Universitas Diponegoro, Semarang. Diakses tanggal 13 Maret 2015

Fitriani, Eka. 2013. Faktor Risiko Yang Berhubungan Dengan Kejadian Tuberkulosis Paru (Studi Kasus di Puskesmas Ketanggungan Kabupaten Brebes Tahun 2012). Unnes Journal of Public Health. 2 (1): $1-7$

Kizito, Kibango Walter., Dunkleya, Sophie., Kingori, Magdalene. and Reidc, Tony. 2010. Lost to follow up from tuberculosis treatment in an urban informal settlement (Kibera), Nairobi, Kenya: what are the rates and determinants?. Transactions of the Royal Society of Tropical Medicine and Hygiene. 105 (2011): 52-57

Lienhardt, Christian. 2001. From Exposure to Disease: The Role of Environmental Factors in Susceptibility to and Development of Tuberculosis. Epidemiologic Reviews. 23 (2): 288-301

Maleche-Obimbo, E., Wanjau, W. and Kathure, I. 2015. The journey to improve the prevention and management of childhood tuberculosis: the Kenyan experience. International Journal Of Tuberculosis and Lung Disease. 19(12):539-542

Mareta, A, 2013. Hubungan antara kondisi fisik rumah dengan kejadian tuberkulosis paru, Ilmu Kesehatan Masyarakat, Universitas Negeri Semarang. Diakses tanggal 10 Maret 2015
Dwi Sarwani S., Nurlaela, Sri. \& A, Isnaini Zahrotul. 2012. Faktor Risiko Multidrug Resistant Tuberculosis (MDR-TB). Jurnal Kesehatan Masyarakat (KEMAS). 8 (1): 60-66

Ruswanto B, 2010. Analisis Spasial sebaran kasus tuberkulosis paru ditinjau dari faktor lingkungan dalam dan luar rumah di Kabupaten Pekalongan, Universitas Diponegoro Semarang. Diakses 20 Juni 2014

Suharyo. 2013. Determinasi Penyakit Tuberkulosis di Daerah Pedesaan. Jurnal Kesehatan Masyarakat (KEMAS). 9 (1): 85-91

Tiwari, Simmi., Kumar, Amod. and Kapoor, S.K. 2012. Relationship between sputum smear grading and smear conversion rate and treatment outcome in the patients of pulmonary tuberculosis undergoing DOTS- A prospective cohort study. Indian Journal of Tuberculosis. 59 (3): 135140

Wankhade, Gauri., Hutke, Vinita., Waghmare, Pranita J., Misra, Arup Kr., Varma, Sushil Kumar., and Harinath, B.C. 2012. Inhibitory effect of isoniazid and orlistat combination on mycobacterial ES-31 serine protease in vitro and on the growth of M.tb bacilli in axenic culture. Indian Journal of Tuberculosis. 59 (3): 156-161

Widoyono, 2008. Penyakit Tropis Epidemiologi, Penularan, Pencegahan dan Pemberantasan, Penerbit Erlangga, Jakarta

Wulandari, Susiani. 2012. Hubungan Lingkungan Fisik Rumah Dengan Kejadian Tuberkulosis Paru. Unnes Journal of Public Health. 1 (1): $42-44$ 